\title{
Digital Posters to Engage EFL Students and Develop Their Reading Comprehension
}

\author{
Samah Zakareya Ahmad ${ }^{1}$ \\ ${ }^{1}$ Faculty of Education, Suez University, Suez, Egypt \\ Correspondence: Samah Ahmad, Faculty of Education, Suez University, Suez, Egypt. E-mail: \\ samahahmad2020@yahoo.com
}

Received: June 10, 2019

Accepted: July 4, 2019 Online Published: July 15, 2019

doi:10.5539/jel.v8n4p169

URL: https://doi.org/10.5539/jel.v8n4p169

\begin{abstract}
This study investigates the effect of digital posters on the reading comprehension and engagement of EFL students. Thirty-three 3rd-year EFL college students were divided into a control group $(\mathrm{n}=17)$ and an experimental group $(\mathrm{n}=16)$. Both groups were pretested on reading comprehension and engagement before the experiment and then posttested after it. For 12 weeks, participants in the control group received their regular instruction while those in the experimental group used digital posters. Using digital posters went through six steps: orientation, preparation, production, presentation, evaluation, and reflection. While Mann-Whitney U Test showed no significant differences between the two groups in the pretest of reading comprehension $(U=118.00$; $p>0.05)$ or engagement $(U=102.00 ; p>0.05)$, it showed significant differences between them in the posttest of reading comprehension $(U=70.00, p<0.05)$ and engagement $(U=57.00, p<0.05)$. This led the researcher to reach the conclusion that digital posters significantly improved the reading comprehension and engagement of EFL students.
\end{abstract}

Keywords: digital posters, EFL students, reading comprehension, student engagement

\section{Introduction}

\subsection{Background to the Problem}

Reading is a crucial means of gaining new knowledge (Hellekjaer, 2009) frequently done for personal, academic, and social purposes (Ghaith, 2018). Viewed as "the goal of reading" (Pugalee, 2015, p. 69) as well as "the heart of reading" (Moore \& Hall, 2012, p. 24), reading comprehension is a key component in learning English as a foreign language (Ahmadi \& Ismail, 2012). It is a multifaceted process (Shin, Dronjic, \& Park, 2019) that involves transforming a text into thought or meaning (Kong, 2019). Therefore, it has a significant impact on academic achievement (Hunter, 2009).

One of the primary factors that influence the development of EFL students' reading is student engagement (Coertze, 2011) as engaged readers gain a richer understanding of what they have read (McGeown, 2013). Therefore, in order to become skilled readers, students must be motivated to get engaged with literacy tasks (Guthrie \& Klauda, 2015). Student engagement represents students' involvement with activities likely to generate high quality learning (Kuh, 2009). It also refers to the extent to which students are motivated to learn and do well in school (Kahu \& Nelson, 2018; Sun \& Rueda, 2012) expressed in their depth of interaction physically and cognitively with the content (Butt, 2014).

Student engagement is a multidimensional construct (Fredricks, Reschly, \& Christenson, 2019) associated with several positive learning and life outcomes. It is strongly related to academic performance (Reeve, 2013), motivation to learn (Barak, Watted, \& Haick, 2016), personal development (Fletcher, 2019), satisfaction (Martin \& Bolliger, 2018), success (You \& Sharkey, 2009), and retention (Leece \& Campbell, 2011). It is also viewed as enhancing students' abilities to become lifelong learners (Field, Schmidt-Hertha, \& Waxenegger, 2015). Moreover, it is considered as a valid indicator of institutional excellence (Axelson \& Flick, 2011) and a measure of how effective institutions are in improving student degree attainment (Nora, Crisp, \& Matthews, 2011).

Despite the necessity of comprehending written English, many students suffer from major difficulties with English reading comprehension which often negatively affect their academic as well as professional lives. This might be due to the complex (Elleman \& Oslund, 2019) and sophisticated nature of EFL reading comprehension 
(Clarke, Truelove, Hulme, \& Snowling, 2014) which usually makes students have difficulties in constructing meaning from written texts (Grabe \& Stoller, 2011). Moreover, sufficient student engagement does not occur for too many students (Appleton, Christenson, \& Furlong, 2008). Engaging students in higher education can be more problematic as many of these students do not feel they belong to the university community (Baik, Naylor, \& Arkoudis, 2015). Moreover, engagement is difficult in large enrollment courses where learners think they have little chance to communicate with their teachers (Salemi, 2009). The consequences of disengagement for these students are severe (Bempechat \& Shernoff, 2012; Fredricks \& McColskey, 2012) because such students are less likely to graduate and usually face limited employment prospects (Fredricks, Ye, Wang, \& Brauer, 2019). Egyptian students are no exception. Some research studies found weaknesses in the reading comprehension of Egyptian EFL students at the primary (e.g., Abdul Aziz, 2016; Mohamed, 2013), preparatory (e.g., Kazamel, 2018; Hassan, 2015), and secondary stages (e.g., Ahmed, 2018; Ali, 2015) as well as at the college level (e.g., El-Koumy, Al-Hady, \& Ahmed, 2007; Mareye, 2019; Soliman, 2014). Some other studies found weaknesses in Egyptian students' engagement (e.g., Abdul Fattah, 2018; Sadik, 2008).

Teaching at the Faculty of Education, Suez University (henceforth FOESU) provided an opportunity for the researcher to notice that many of her students did not possess enough reading comprehension skills that would enable them to participate efficiently in academic activities. Moreover, they were not engaged enough with their study, which might be the reason for their unsatisfactory academic performance. Therefore, she administered a reading comprehension test and a student engagement questionnaire to a group of EFL students at the FOESU which revealed that many of these students suffered problems with their reading comprehension as well as their engagement.

\subsection{Problem Statement}

The present study's problem was the weaknesses in EFL students' reading comprehension and engagement. For the sake of finding a solution to this problem, the researcher decided to use digital posters.

\subsection{Review of Related Literature}

\subsubsection{Traditional Posters}

Posters have been used for many purposes including: political campaigns, public health warnings, and advertising (Bethell \& Milson, 2014). Moreover, the poster presentation has been used as an alternative to paper presentations at many academic conferences (Lagares \& Reisenleutner, 2017). Posters can attract viewers' attention and interest (Izatt \& Dadiz, 2015) while being inexpensive to produce (Ilic \& Rowe, 2013). Moreover, they facilitate the fast and efficient delivery of key ideas (Bethell \& Milson, 2014) through providing a summarized overview of the topic (Ilic \& Rowe, 2013). Teachers have long guided their learners to work with posters to display what they learned (Hodgson, 2010) as using posters is a useful approach to create a different learning mood (Abdul Aziz \& Jusoff, 2009). Moreover, poster sessions have been successfully used in professional development programs (Morales \& Morales, 2017).

Posters have many benefits in the educational context. They are colorful, attractive learning media (Coşkun \& Eker, 2018) which cater for different learning styles (El-Sakran \& Prescott, 2015) and which create a more stimulating and interesting class environment (Prichard \& Ferreira, 2014). Moreover, they allow for creativity (Abdul Aziz \& Jusoff, 2009), individuality (D’Angelo, 2011), originality (Cook \& Fenn, 2013), and independent thought (D'Angelo, 2010). They also promote students' autonomy (El-Sakran \& Prescott, 2015), fluency (Tanner \& Chapman, 2012), research skills (D’Angelo, 2010), transferable skills (Chun, 2010), confidence (Bethell \& Milson, 2014), positive attitudes (Cook \& Fenn, 2013), presentation skills (Conteh, 2018), and collaborative learning (D'Angelo, 2010). Posters also give students opportunities to reflect on what they learned (McNamara, Larkin, \& Beatson, 2010), to highlight their different strengths (Kinikin \& Hench, 2012), to receive feedback from their peers and faculty (Billings \& Halstead, 2012), and to share what they have learned with their classmates (Kinikin \& Hench, 2012). Additionally, they help students organize their thoughts (Bethell \& Milson, 2014), explore misconceptions about a topic (Cook \& Fenn, 2013), demonstrate learning (McNamara et al., 2010), and make a stronger connection between the skills required to find the information and students' ability to communicate what they have acquired (Kinikin \& Hench, 2012). Finally, they ease the grading burden on instructors (D'Angelo, 2010) and give them a glimpse into the thinking of students (Hodgson, 2010).

In the language classroom, particularly, poster presentations make students use language for real-life goals (Tanner \& Chapman, 2012) as they engage them in real communicative activities (El-Sakran \& Prescott, 2015). Moreover, they develop students' oral and written communication skills (Bethell \& Milson, 2014; McNamara et al., 2010) through lessening their speaking anxiety (Prichard \& Ferreira, 2014). They also allow them to produce their own texts (El-Sakran \& Prescott, 2015). 
Although there is no single way to design a poster (Carter, 2013), researchers suggest some guidelines for creating effective ones. For example, posters should be attractive and striking through the use of color and visuals such as photos, illustrations, graphs, maps, charts, diagrams, and tables (Lyddon \& Selwood, 2017). Moreover, information contained in the poster should be presented in a clear (Gastel \& Day, 2016) and well-organized format to ensure both coverage and clarity (D'Angelo, 2011). In this respect, Carter (2013) highlights the importance of reducing text in posters. He recommends that the total word count for any poster should range from 600 to 800 words because a text-heavy poster puts off readers (Driskill, 2010). Additionally, an effective poster should convey intended messages (Yang \& Hsu, 2015). Finally, the information presented in posters should be accompanied by an oral presentation to enhance the communication of the content (Rowe \& Ilic, 2009).

Many studies that investigated students' and teachers' views about poster presentations showed that they found the poster activity helpful. The results of small-group interviews conducted by Doğan, Kaya, Kiliç, Kiliç, and Aydoğdu (2004) showed that prospective teachers described their poster presentations as a funny way of learning. Those teachers also expressed that their poster presentations made the knowledge they gained more permanent and increased their curiosity and interest. In the study of El-Sakran and Prescott (2015), students appreciated the poster experience and asked for using it more in the future. Also, in the study of Abdul Aziz and Jusoff (2009), students' reflection indicated that the poster was interesting and captured their attention to look further and learn with impact. Finally, analysis of the responses from the exit survey conducted by Dzekoe (2013) showed that the poster activity helped students discover specific information and important words and phrases that helped them revise their written text.

However, traditional posters have their own unique downsides. For example, the poster creation process produces a static final product (Cook, 2013) which reaches a limited audience and often ends up in the trashcan (Cabrejas Penuelas, 2013). Moreover, the traditional poster contains fixed information (Hodgson, 2010) and offers so little space for text and graphs (D'Angelo, 2012). Therefore, there is a need to improve the quality and thus the impact of traditional posters. That is the reason digital posters have appeared as an alternative to the traditional paper poster.

\subsubsection{Digital Posters}

Due to its multimodal nature, the poster tends to change rapidly with technology (D'Angelo, 2012). The evolution of the Internet has presented educators with numerous possibilities for integrating technology into teaching and learning (Ahmed, 2014; Richardson, 2010). Moreover, Web 2.0 tools offer enormous potential for teachers and students. Digital posters are one of such Web 2.0 tools (Cabrejas Penuelas, 2013). Masters, Gibbs, and Sandars (2015) predict that just as people consider web technology as the norm, digital posters will also become the norm.

The digital poster (Alizadeh, Mehran, Koguchi, \& Takemura (2017) is also known as online poster (Hodgson, 2010), virtual poster (Basque, Dao, \& Contamine, 2008), multimedia poster (Roessing, 2014), electronic poster (Masters et al., 2015), and glog (Bender \& Walker, 2013). It is a flexible online poster that combines text, photos, music, videos, hyperlinks, and data attachments into a single presentation (Dzekoe, 2013). Such multimedia can be downloaded from the Internet or the hard drive of a computer, linked to other web pages, or recorded from a video camera (Cabrejas Penuelas, 2013). Some educators suggest using regular computer software for producing the digital poster such as Rushton, Middleton, and Malone (2014) who view the digital poster as a short presentation that is visually rich, recorded using screen capture technology. The recording is then saved as a digital video file and can be replayed inside or outside the classroom. Some other educators (e. g., Bustamante, Hurlbut, \& Moeller, 2012; Dzekoe, 2013) suggest creating digital posters using an online generator such as Glogster, a multimedia website where teachers can create and access different accounts for individuals or groups of students and where students can create and share interactive posters, upload existing files and edit them, and use a variety of templates.

The digital poster offers more advantages over its traditional counterpart. First, a digital poster offers an "open palette" (Molloy \& Boyle, 2014, p. 25) to include a large volume of information, as there are fewer restrictions on word count and size of figures and tables (Fraser, Fuller, \& Hutber, 2009). Moreover, the possibility to hyperlink the content of a poster is very helpful because it eliminates the difficulties related to limitation of space typical of traditional paper posters (D'Angelo, 2016). Second, it is a fun and innovative tool (Dinica, Dinescu, \& Miron, 2012) which offers a new environment (Rushton et al., 2014) that is more interesting than a lecture or a bulleted PowerPoint show (Bozarth, 2010). The drag-and-drop interface containing text, images, audios, videos, and drawings is a very attractive and user-friendly tool for learners (Cabrejas Penuelas, 2013). Third, it allows 
students to share knowledge (Dinica et al., 2012) fulfilling their desire to inform others about an issue in a multimedia format (Bender \& Walker, 2013; Pedwell, Hardy, \& Rowland, 2017) and enabling a wider audience to reach than is possible during face-to-face poster presentations (D'Angelo, 2016). This can motivate students to produce work of a higher quality (Buck Institute for Education, 2013). Fourth, it facilitates scientific communication (Shin, 2012) and enables the audience to interact with the author both synchronously and asynchronously (Hai-Jew, 2012) allowing feedback to reach poster presenters (D'Angelo, 2016). Fifth, it costs next to nothing and saves time for presenters (D'Angelo, 2012) who do not have to worry about printing and carrying the poster to the event (Saver, 2014).

Many of the guidelines from creating traditional posters still apply to digital posters (Saver, 2014). However, more rules can be introduced for digital posters. In terms of design, digital poster designers should be consistent with typefaces, colors, and spacing as well as use layout gridlines to help line things up (Molloy \& Boyle, 2014). Moreover, Masters et al. (2015) believe that designers should use a bigger font than they would regularly use on a traditional poster. In terms of content, they advise designers to resist the temptation to stuff the poster with too much information which can overwhelm the audience. Additionally, Molloy and Boyle (2014) advise digital poster designers not to neglect simple things like spelling and to get the project proof-read by someone who is not connected to it. More guidelines for creating digital posters are related to their quality and mechanical performance. These include: using a technical interface that does not raise anxiety (Rushton et al., 2014); checking the graphic resolution of images; making sure the embedded links work; setting moving animation to a medium speed (Molloy \& Boyle, 2014); using the best quality possible for videos, audio, and graphics; adding subtitles to animations and videos; placing clickable thumbnails on the main page that take the viewer to a larger version of the images (Masters et al., 2015); and making the poster interactive by putting a feedback link for comments or a hyperlinked email icon (Molloy \& Boyle, 2014).

Teachers' and students' views about digital posters were investigated in many studies. In Angelini's (2014) study, teachers expressed that making their students participate in the design of a digital poster resulted in a more satisfying experience. Teachers in Cook's (2013) study viewed digital posters as the way of the future and expressed that they should be integrated into modern curriculums. They also pointed out that digital posters were an attractive way to present information, provided flexibility for students to create and present, and gave students the freedom to be creative. A thematic analysis of teachers' responses to a survey conducted by Cook and Fenn (2013) revealed that they viewed the benefits of digital posters as: ease of collaboration (54\%), ease of communication and interaction with audience (26\%), and creativity $(20 \%)$.

As for students' views about the digital poster, the results of a questionnaire administered by Shin (2012) to 78 students showed preference for digital posters over traditional ones. In the study of Rushton et al. (2014), students positively perceived the task as being fun, interesting, as well as an efficient method to engage attention. Students participating in Martinez-Alba, Cruzado-Guerrero, and Pitcher's (2014) study enjoyed using digital posters and believed that using out of the box resources on the Internet stimulated them to read and write more. They also expressed that the digital posters helped lessen the gap between how students acquired knowledge and literacy inside and outside of the classroom. In Basque et al.'s (2008) study, all respondents enjoyed and learned from the digital poster session while in Sabo's (2013) study, students appreciated having autonomy when creating their digital posters and found the interactive tools contributing to lively, enthusiastic intervention sessions.

Whereas no empirical studies have tackled the effect of digital posters on EFL students' reading comprehension, few studies found digital posters to improve student engagement (Angelini, 2014; Cook, 2013; Cook \& Fenn, 2013; Rushton et al., 2014). This study aims to fill these needs by exploring the use of digital posters to engage EFL students and develop their reading comprehension.

\subsection{Hypotheses of the Study}

1.4.1 No statistically significant difference $(\alpha \leq 0.05)$ would exist in third-year EFL students' reading comprehension between the experimental group exposed to digital posters and the control group exposed to regular classroom instruction.

1.4.2 No statistically significant difference $(\alpha \leq 0.05)$ would exist in third-year EFL students' engagement between the experimental group exposed to digital posters and the control group exposed to regular classroom instruction. 


\section{Method}

\subsection{Research Design}

A pretest-posttest control-group design was adopted where: (1) the reading comprehension and engagement pretests were administered to all participants, (2) participants were randomly divided into a control group and an experimental group, (3) the control group experienced regular classroom instruction while the experimental group experienced the use of digital posters, (4) posttests were administered to all participants, and (5) differences between the two groups in both the pretests and posttests were evaluated.

\subsection{Variables}

An independent variable (digital posters) and two dependent variables (reading comprehension \& student engagement) were included in the study. All variables are operationally defined below.

\subsubsection{Digital Poster}

A digital poster is a collaborative communicative multimedia representation of the information students collected and analyzed about an assigned topic. It is designed and created online using the GlogsterEdu website which allows students to integrate multiple modes, such as written text, photos, audios, videos, drawings, links, data attachments, and other media into a single attractive file.

\subsubsection{Reading Comprehension}

Reading comprehension is comprehending information and ideas included in English written texts and that comprehension is represented in the ability to identify the main idea, identify supporting details, guess meaning, infer causes, and make justified choices.

\subsubsection{Student Engagement}

Student engagement is the extent to which students participate in practices related to high levels of learning including participation in collaborative learning experiences, faculty-student contact, and number of hours spent per week on school-, non-school-, family-, work- and extra-curricular-related activities.

\subsection{Participants}

Participants were 33 third-year students of EFL at FOESU (17 in the control group and 16 in the experimental group). All of them studied EFL for at least 10 years. Their ages ranged between 20-22 years.

\subsection{Measures}

\subsubsection{Reading Comprehension Test}

This test was used as pretest and posttest to measure participants' reading comprehension before and after the treatment. Two reading comprehension passages were carefully selected to suit students' comprehension level. The content of the passages was related to what students would read during the treatment and to their academic study. Each passage was followed by five multiple-choice questions, each measuring one of the following reading comprehension skills: (a) identifying the main idea, (b) identifying supporting details, (c) guessing the word meanings from context, (d) inferring causes, and (e) making justified choices. Each question was assigned two marks. Scores on the test could range from zero to 20 marks.

The test was administered to a pilot group of third-year EFL students at FOESU. The purpose was to find out whether the passages and the questions were clear and understandable to the students and how much time students would take in answering the test. As for the first point, it was observed that the passages were a little bit difficult for the students. So, the tests were modified so that the passages became simpler. Concerning the time needed for answering the test, it was estimated by calculating the mean of time of both the fastest and slowest students that finished answering the test. Therefore, an hour was enough for answering the test. To determine face validity, a questionnaire developed by the researcher asked seven specialists working in the field of TEFL to review the test. Reviewers' suggestions were taken into consideration. To ensure reliability, the test was administered twice to 40 EFL students at FOESU. The time between the two administrations was two weeks to make sure that students would not remember their answers from the first administration. Correlation coefficient was 0.76 , significant at the 0.05 level.

\subsubsection{Student Engagement Questionnaire}

The instrument used to measure participants' engagement was adapted from the National Survey of Student Engagement (NSSE). The NSSE is a self-report tool that measures the extent to which students are involved in educational activities related to high levels of learning and development. Since it was launched in 2000, 
approximately 6 million students at over 1,600 colleges and universities have completed the NSSE (National Survey of Student Engagement, 2019). For Axelson and Flick (2011), most college teachers immediately think of the NSSE whenever they hear the term student engagement.

Thirty-seven items were selected from the NSSE, consistent with the adopted definition of student engagement. The resulting instrument was called Student Engagement Questionnaire (SEQ). The SEQ was administered to a sample of 45 EFL students at FOESU in order to collect their comments on the readability and clarity of the items of the questionnaire. Accordingly, items that were ambiguous were rewritten. Moreover, items where most students were giving the same score were eliminated as they did not differentiate among respondents. Based on item-total correlation analysis, three items were discarded due to low item-total correlation $(\mathrm{r}<0.15)$. The final number of items was 29. The questionnaire followed a four-point Likert scale. Items 1-18 were answered on a scale that varied from 1 = "Never", 2 = "Often", 3 = "Sometimes", and $4=$ "Very often" while responses for items 19-23 ranged from 1 = "Very little", 2 = "Some", 3 = "Quite a bit", and 4 = "Very much". Finally, items 24-29 were coded with responses $1=$ "0-10", $2=$ "11-20", $3=$ "21-30", and $4=$ " $>30 "$ ". Scores on the SEQ could range from 29 (the minimal score) to 116 (the maximal score).

The SEQ was reviewed by some TEFL specialists as well as educational psychologists who decided it was suitable for Egyptian EFL students. Moreover, criterion validity was examined by assessing the correlation of this measure to another measure of student engagement. A group of EFL students at FOESU, were asked to respond not only to the SEQ but also to Jamaludin and Osman's (2014) questionnaire of student engagement. Participants' scores on the two scales were significantly correlated (Pearson's coefficient of correlation was 0.743). To insure reliability, a group of EFL students at FOESU performed the SEQ twice with a two-week interval. The two administrations were correlated and Pearson's coefficient of correlation was 0.911 . Moreover, the split-half method was employed. The scale was randomly divided into two halves and Pearson's coefficient of correlation for these half-tests was 0.852 . This coefficient had to be adjusted so that it could be interpreted as full-test reliability. This adjustment was accomplished by using the Spearman-Brown Prophecy formula (Brown, 1996, p. 195). Therefore, full-test reliability was 0.920 . All coefficients reached the 0.01 level of significance.

\subsection{Procedures}

Procedures were executed at FOESU during the first term of the 2017/2018 academic year. First, all participants were pretested on reading comprehension and student engagement. Then, participants were randomly divided into a control group and an experimental group. After that and for 12 weeks, the control group participants received their usual instruction while the experimental group participants used digital posters. Finally, all participants were posttested on reading comprehension and student engagement. Using digital posters went through the following six steps:

\subsubsection{Orientation}

At the beginning of the academic term, students attended two digital poster training sessions. The first was done in class and lasted 30 minutes during which the researcher presented the idea of digital posters, offered some examples, and answered students' questions. The researcher informed participants that they were going to use GlogsterEDU, an online digital poster creation tool which allows users to insert text, pictures, audio files, YouTube videos, clip art, and various backgrounds. Glogster is actually a free online poster generator website. It has a public site that can be used by anyone. Unfortunately, it is not suitable for students because of some of the content posted there by casual users. Therefore, the researcher decided to use GlogsterEDU, an educational division of the same website which is safe to use with students.

The second session lasted a whole hour and took place in the computer lab. During this session, the researcher began by modeling the process and showing students how to use the GlogsterEdu site for creating digital posters. Then, students explored the website and practiced using it with content of their choice. They also accessed online digital poster samples which demonstrated to the students what is expected in their posters and how to design high quality posters.

Participants were informed that an online discussion group would be used as a platform for discussing and using the digital posters. Content on that discussion group could only be seen by group members so that participants would freely write and post whatever they liked. On this discussion page, the researcher posted several tutorial videos for students in order to learn how to use the GlogsterEDU website in creating their digital posters. She also answered students' questions and offered several examples of digital posters. As an additional means of support, an illustrated digital poster creation guide was developed by the researcher and posted to the group page. 


\subsubsection{Preparation}

After the training sessions, participants in the experimental group self-organized into four teams, each consisting of 3-5 participants. Each week, a topic related to the course (TEFL for Special Needs) was assigned. Members in each group had to search for and read online materials (books, articles, and other sources). Participants read for two purposes: (1) in order to compile an initial base of information for creating their digital posters and (2) in order to obtain adequate background knowledge that would enable them to review their peers' digital posters and offer them feedback to improve these posters. Therefore, participants collected, summarized, and made notes on information that would be included in the digital posters. Besides preparing content in the written form, students were also required to include at least two multimodal elements in their digital posters. Therefore, they collected images, graphs, sound files, video files, and website links related to their assigned topic.

\subsubsection{Production}

After collecting the required multimedia content, students used the GlogsterEDU website to create digital posters that would reflect their understanding of the content they had read. They could use existing templates, images, and audiovisual media or import the text, images, videos, and links they previously prepared. To help participants create their posters, a rubric was posted by the researcher at the start of the semester. This rubric outlined the elements to be included in the posters. These elements were: poster title, section titles, text, hyperlinks to resources of the information included in the poster in addition to at least two multimodal elements (picture, video file, audio file, etc.). The rubric also included assessment criteria. These criteria were: overall format, accuracy of information, use of English, and technical aspects (e. g., sound and image quality). Participants also used the guide developed by the researcher in creating their digital posters. They also posted questions on the discussion board to ask for help from both the researcher and peers.

\subsubsection{Presentation}

After completing the digital posters based on the assigned topic, each group uploaded their poster to the online discussion group which served as a digital poster gallery where students could view and comment on each other's work. This created an audience for the posters, which allowed for peer assessment and reflection.

\subsubsection{Evaluation}

All participants were required to examine their colleagues' posters and post comments to the discussion board. They were also encouraged to comment on others' views. These comments included the points of strength and weakness in each poster as well as suggestions for improvement. Participants were encouraged to use the rubric posted to their discussion board in their evaluation. Groups edited their digital posters based on the comments offered by the researcher and other participants and posted them again.

\subsubsection{Reflection}

Students were required to write their reflections on the approach as a whole. To organize the reflections, the researcher provided specific questions to prompt detailed analysis including: (a) What do you think about using digital posters for presenting your reading? (b) What progress have you achieved in learning how to use them? (c) What questions do you have about how to use them, (d) What were the challenges you confronted? (e) What are the points of strength and weakness in your poster? and (f) What modifications do you need to do to your poster? The reflections were posted to the discussion group and students were encouraged to comment on their classmates' narratives.

\section{Results}

\subsection{Result for Reading Comprehension}

Mann-Whitney U Test was employed for testing the difference between the two groups' mean scores in the reading comprehension pretest and posttest. It did not indicate a significant difference between the two groups in the pretest $(\mathrm{U}=118.00 ; \mathrm{p}>0.05)$ but indicated a significant difference between them in the posttest $(\mathrm{U}=70.00$; $\mathrm{p}<0.05$ ). These results are summarized in Tables 1 and 2 . 
Table 1. Mann-Whitney U Test of the difference between the mean score of the control group and that of the experimental group in the reading comprehension pretest

\begin{tabular}{llllll}
\hline Group & $\mathrm{N}$ & Mean Rank & Sum of Ranks & Mann-Whitney U & Significance \\
\hline Control & 17 & 18.06 & 307.00 & 118.00 & .509 \\
Experimental & 16 & 15.88 & 254.00 & & \\
Total & 33 & & & & \\
\hline
\end{tabular}

Table 2. Mann-Whitney U Test of the difference between the mean score of the control group and that of the experimental group in the reading comprehension posttest

\begin{tabular}{llllll}
\hline Group & $\mathrm{N}$ & Mean Rank & Sum of Ranks & Mann-Whitney U & Probability \\
\hline Control & 17 & 13.12 & 223.00 & 70.00 & .016 \\
Experimental & 16 & 21.12 & 338.00 & & \\
Total & 33 & & & & \\
\hline
\end{tabular}

\subsection{Result for Student Engagement}

Mann-Whitney U Test was also employed for testing the difference between the two groups' mean scores in the student engagement pretest and posttest. Whereas it did not indicate a significant difference between the two groups in the pretest $(\mathrm{U}=102.00 ; \mathrm{p}>0.05)$, it indicated a significant difference between them in the posttest ( $\mathrm{U}$ $=57.00 ; \mathrm{p}<0.05)$. These results are summarized in Tables 3 and 4 .

Table 3. Mann-Whitney U Test of the difference between the mean score of the control group and that of the experimental group in the student engagement pretest

\begin{tabular}{llllll}
\hline Group & $\mathrm{N}$ & Mean Rank & Sum of Ranks & Mann-Whitney U & Probability \\
\hline Control & 17 & 19.00 & 323.00 & 102.00 & .220 \\
Experimental & 16 & 14.88 & 238.00 & & \\
Total & 33 & & & & \\
\hline
\end{tabular}

Table 4. Mann-Whitney U Test of the difference between the mean score of the control group and that of the experimental group in the student engagement posttest

\begin{tabular}{llllll}
\hline Group & $\mathrm{N}$ & Mean Rank & Sum of Ranks & Mann-Whitney U & Probability \\
\hline Control & 17 & 12.35 & 210.00 & 57.00 & .004 \\
Experimental & 16 & 21.94 & 351.00 & & \\
Total & 33 & & & & \\
\hline
\end{tabular}

\section{Discussion}

As for reading comprehension, using Mann-Whitney U Test did not yield any difference with statistical significance between the two groups' mean scores in the pretest $(U=118.00 ; p>0.05)$. However, it indicated a statistically significant difference between them in the posttest $(U=70.00 ; p<0.05)$. Based on this result, the researcher rejected the first hypothesis of the study and concluded that digital posters can improve EFL students' reading comprehension. This result might find support in the findings of a single study (Murdiani, 2013) which found that students taught using posters improved in reading comprehension. An explanation for this result is the extensive reading that students of the experimental group practiced in order to collect material to be included in their digital posters. As explained by Nation (2009), students' reading comprehension can develop exponentially when exposed to large quantities of relevant reading texts for a long period of time. This idea is confirmed by the results of a number of research studies that showed the effectiveness of extensive reading in improving reading comprehension (e. g., Huffman, 2014; Suk, 2017). A second explanation is that during the digital poster creation process, students had to acquire a deeper comprehension of the material they read in order to be able to demonstrate their understanding of this content in different media (text, pictures, graphics, audio, and video) conveyed through their digital posters. That is, in order to prepare their digital posters, they returned to the text multiple times and looked at it from different perspectives. This is pointed out by Kinikin and Hench (2012) who believe that posters require that students assimilate the information they find to explain what they have learned about their topic.

A third explanation for this result is that online reading was beneficial for improving participants' reading 
comprehension. This might be because students become more motivated to read when they have the opportunity to read online (Pitcher, Martinez-Alba, Dicembre, Fewster, \& McCormick, 2010). In this respect, some studies found that using technology improves reading comprehension (Huang 2014; Liu, Chen, \& Chang, 2010; Pernjek $\&$ Habjanec, 2015; Pratama, 2015). A fourth explanation for this result is that the digital poster creation process was cooperative. That is, participants formed teams and assigned roles for each team member. They discussed and negotiated the best way to present their information in the digital posters. During this process, students read and re-read their notes and then synthesized the information to accommodate the digital poster format. This explanation is supported by the results found by Liao and Oescher (2009) as well as Suh (2009) that show the positive effect of cooperative learning with EFL students in reading classes. It is also supported by the results of some studies (e.g., Khori \& Ahmad, 2019) which displayed that integrating cooperative learning with EFL reading instruction improves reading comprehension. A final explanation for this result is that the discussion and interaction about the assigned topic and the resulting digital posters that took place in the discussion board might have improved participants' reading comprehension. This explanation is supported by Pan and Wu's (2013) assertion that learning EFL reading requires more interaction. It is also supported by a number of studies that found that instruction that incorporates social interaction about text increases students' reading comprehension (e. g., Christ, Wang, \& Chiu, 2015; Gambrell, Hughes, Calvert, Malloy, \& Igo, 2011).

As for students' engagement, Mann-Whitney U Test also did not indicate a statistically significant difference between the two groups' mean scores in the pretest $(U=102.00 ; p>0.05)$ despite showing a significant difference between them in the posttest $(U=57.00 ; p<0.05)$. Based on this result, the researcher rejected the second hypothesis and concluded that digital posters had a significant effect on the engagement of EFL students. This result goes along with Hasio's (2015) contention that posters help students engage in learning. Moreover, this result might find support in the findings of some studies (Angelini, 2014; Cook, 2013; Cook \& Fenn, 2013; Kinikin \& Hench, 2012; Rushton et al., 2014) which found posters (whether traditional or digital) to be helpful in improving student engagement. This result is also supported by prior literature in the field of student engagement. That is, there is some evidence that some characteristics of digital posters may have led to enhancing the engagement of the participants. The first of these characteristics is that the digital poster is based on using technology and multimedia to support learning. This agrees with the results of various studies (e.g., Draus, Curran, \& Trempus, 2014; Malin, 2010; Pond, 2016) which found the use of technology and multimedia to improve student engagement. This explanation is supported by Cook (2013) who thinks that better student engagement can be achieved by developing digital literacy skills. He adds that students engage better with the digital poster task because what they create is to be shared online, which gives them better opportunities for full group participation.

The second explanation is that the digital poster is based on active learning. This agrees with the assertion of Wolf-Wendel, Ward, and Kinzie (2009) as well as Mustafa et al. (2019) that higher student engagement is correlated with active learning. Moreover, according to the National Survey of Student Engagement (2019), students are engaged in learning when they are actively involved in challenging learning tasks, particularly those involving collaboration with peers. This also agrees with the results of some studies (e. g., Juergensen, Oestreich, Yuhnke, \& Kenney, 2015; Popkess, 2010) which found that active learning increased engagement. The third explanation for this result is the support provided by the researcher during the implementation of the digital posters. As pointed out by Chong, Kit, Liem, Ang, and Huan (2017), student engagement is positively associated with teacher support. In this respect, Reeve and Tseng (2011) declare that students' engagement exists when there is an instructional support and a relationship with the teacher during learning activities.

The fourth explanation is that posters are student-centered (McNamara et al., 2010). As confirmed by Biggs and Tang (2011), student-centered approaches are important to motivating students and thus achieving their engagement. As Bender and Walker (2013) put it, the user-driven process of creating digital posters engages students completely, allowing them to spend more time with classroom content while also building digital literacy skills. The final explanation for this result is the simple production process of digital posters. In the present study, participants used the GlogsterEdu website which is easy and highly accessible and does not require students to possess sophisticated technical skills as content was placed and replaced at the simple click of a mouse. Therefore, the digital poster production process does not raise anxiety in participants (Prichard \& Ferreira, 2014). As Peregoy and Boyle (2016) confirm, to get students engaged, the activity should be enjoyable and interesting. For many educators (e. g., Dinica et al., 2012; Stegemann \& Sutton-Brady, 2009), the digital poster is a fun, attractive, and innovative tool.

\section{Conclusion}

Based on the results of the present study, the researcher concluded that digital posters improved the reading 
comprehension and engagement of EFL students.

\section{Recommendations and Suggestions}

The researcher recommends: 1) devoting more attention to increasing EFL students' reading comprehension and engagement, 2) encouraging EFL learners to be producers as well as consumers of content, 3) encouraging them to read online materials, and 4) providing them opportunities to include multimodal elements (e. g., images, sound, video, graphs, etc.) in their learning projects. Moreover, she suggests conducting studies tackling: 1) the impact of digital posters on EAP students' communication skills, 2) EFL learners' attitude towards using traditional versus digital posters, 3) the effect of other technological tools (e.g., e-mails, discussion boards, webquests) on student engagement, and 4) a comparison of the effect of the traditional versus digital posters on EFL students' writing performance.

\section{References}

Abdul Aziz, A. (2016). The effectiveness of a suggested multiple intelligence-based program in improving primary sixth graders' vocabulary acquisition \& use, reading comprehension skills, \& motivation. Unpublished master's thesis., Minia University, Egypt.

Abdul Aziz, R., \& Jusoff, K. (2009). Effective poster teaching strategy towards risk in studying fraud. International Education Studies, 2(1), 158-162. https://doi.org/10.5539/ies.v2n1p158

Abdul Fattah, S. (2018). An edutainment-based program to develop EFL pronunciation skills \& engagement among students at faculty of education. Unpublished master's thesis, Benha University.

Ahmadi, M., \& Ismail, H. (2012). Reciprocal teaching as an important factor of improving reading comprehension. Journal of Studies in Education, 2(4), 153-173. https://doi.org/10.5296/jse.v2i4.2584

Ahmed, S. (2014). The effect of vlogging on EFL student teachers' teaching self-efficacy. Journal of the Association of Arab Educators, 55, 207-240. https://doi.org/10.21608/saep.2014.25331

Ahmed, S. (2018). A proposed program based on literature circles for developing secondary stage students reading comprehension skills \& attitudes towards studying English. Unpublished doctoral dissertation, Damietta University, Egypt.

Ali, A. (2015). The effect of webquest strategy on developing EFL reading comprehension skills \& cultural awareness of experimental secondary school students. Unpublished doctoral dissertation, Minufiya University, Egypt. https://doi.org/10.1109/ECONF.2015.73

Alizadeh, M., Mehran, P., Koguchi, I., \& Takemura, H. (2017). Learning by design: Bringing poster carousels to life through augmented reality in a blended English course. Paper presented at the EUROCALL 2017 Conference, Southampton, United Kingdom, August 23-26. https://doi.org/10.14705/rpnet.2017.eurocall2017.680

Angelini, L. (2014). Qualitative research on simulation \& collaborative learning. Journal of the Comenius Association, 23, 24-27.

Appleton, J., Christenson, S., \& Furlong, M. (2008). Student engagement with school: Critical conceptual \& methodological issues of the construct. Psychology in the Schools, 45(5), 369-386. https://doi.org/10.1002/pits.20303

Axelson, R., \& Flick, A. (2011). Defining student engagement. Change, 43(1), 38-43. https://doi.org/10.1080/00091383.2011.533096

Baik, C., Naylor, R., \& Arkoudis, S. (2015). The first-year experience in Australian universities: Findings from two decades, 1994-2014. Melbourne, Australia: Centre for the Study of Higher Education, The University of Melbourne.

Barak, M., Watted, A., \& Haick, H. (2016). Motivation to learn in massive open online courses: Examining aspects of language \& social engagement. Computers \& Education, 94, 49-60. https://doi.org/10.1016/j.compedu.2015.11.010

Basque, J., Dao, K., \& Contamines, J. (2008). Authentic e-learning in a virtual scientific conference. In T. Hansson (Ed.), Handbook of research on digital information technologies: Innovations, methods, \& ethical issues (pp. 176-190). New York: Information Science Reference. https://doi.org/10.4018/978-1-59904-970-0.ch013

Bempechat, J., \& Shernoff, D. (2012). Parental influences on achievement motivation \& student engagement. In S. Christenson, A. Reschley \& C. Wylie (Eds.), Handbook of research on student engagement (pp. 315-342). 
New York: Spriner Science. https://doi.org/10.1007/978-1-4614-2018-7_15

Bender, W., \& Walker, L. (2013). Cool tech tools for lower tech teachers: 20 tactics for every classroom. Thousand Oaks, California: Corwin. https://doi.org/10.4135/9781483387840

Bethell, E., \& Milson, C. (2014). Posters \& presentations. Hampshire: Palgrave Macmillan. https://doi.org/10.1007/978-1-137-35709-0

Biggs, J., \& Tang, C. (2011). Teaching for quality learning at university: What the student does (4th ed.). Buckingham: The Society for Research into Higher Education \& Open University Press.

Billings, D., \& Halstead, J. (2012). Teaching in nursing: A guide for faculty (4th ed.). St. Louis, MO: Saunders Elsevier.

Bozarth, J. (2010). Social media for trainers: Techniques for enhancing \& extending learning. San Francisco: Wiley.

Brown, J. (1996). Testing in language programs. New Jersey: Prentice Hall.

Buck Institute for Education. (2013). What is PBL? Retrieved March 24, 2017 from: http://www.bie.org/about/what_is_pbl/

Bustamante, C., Hurlbut, S., \& Moeller, A. (2012). Web 2.0 \& language learners: Moving from consumers to creators. In T. Sildus (Ed.), Touch the world: Selected papers from the 2012 Central States Conference on the Teaching of Foreign Languages (pp. 109-131). Milwaukee, WI: Crown Prints.

Butt, A. (2014) Student views on the use of a flipped classroom approach: Evidence from Australia. Business Education \& Accreditation, 6(1) 33-43.

Cabrejas Penuelas, A. (2013). The use of glogs in the English language classroom. Revista d'Innovacio Educativa, 10, 68-74. https://doi.org/10.7203/attic.10.1775

Carter, M. (2013). Designing science presentations: A visual guide to figures, papers, slides, posters, \& more. London: Academic Press.

Chong, W., Kit, P., Liem, G., Ang, R., \& Huan, V. (2017). Promoting student engagement: Interplay of perceived self-beliefs \& teacher support in fostering positive youth development. Paper presented at the Redesigning Pedagogy International Conference May 31- June 2, 2017, Singapore.

Christ, T., Wang, X., \& Chiu, M. (2015). Emergent readers' social interaction styles \& their comprehension processes during buddy reading. Literacy Research \& Instruction, 54(1), 45-66. https://doi.org/10.1080/19388071.2014.968301

Chun, M. (2010). Taking teaching to performance task: Linking pedagogical \& assessment practices. Change, 42(2), 22-29. https://doi.org/10.1080/00091381003590795

Clarke, P., Truelove, E., Hulme, C., \& Snowling, M. (2014). Developing reading comprehension. Chichester West Sussex, UK: Wiley. https://doi.org/10.1002/9781118606711

Coertze, L. (2011). An investigation of ESL students' reading engagement \& language output in selected online environments. Unpublished master's thesis, Iowa State University.

Conteh, B. (2018). Using electronic posters to assess first year students' research projects. Lonaka JoLT, 9(2), 107.

Cook, R. (2013). CoWs, Google \& online possibilities: Creating digital posters to enhance student engagement. In K. Ragupathi \& A. Soong (Eds.), Technology enhanced learning: Towards an engaging \& meaningful digital future, 7-8 Oct 2013. Singapore: National University of Singapore.

Cook, R., \& Fenn, P. (2013). Dynamic digital posters: Making the most of collaborative learning spaces. In H. Carter, M. Gosper \& J. Hedberg (Eds.), Proceedings of 30th Ascilite Conference, Electric Dreams (pp. 195200). Sydney, New South Wales.

Coşkun, I., \& Eker, C. (2018). The effect of teaching activities done by using activity-based posters on the students' academic achievements, retention levels in their learning. Universal Journal of Educational Research, 6(4), 585-597. https://doi.org/10.13189/ujer.2018.060402

D’Angelo, L. (2010). Creating a framework for the analysis of academic posters. Language Studies Working Papers, 2, 38-50.

D’Angelo, L. (2011). Academic Posters across disciplines: A preliminary study. Language Studies Working Papers, 3, 15-28. 
D’Angelo, L. (2012). From posters to e-posters: The evolution of a genre. Language Studies Working Papers, 4 , 46-54.

D’Angelo, L. (2016). The academic poster genre: Friend or foe. In K. Hayland \& P. Shaw (Eds.), The Routledge handbook of English for academic purposes (pp. 392-402). New York: Routledge. https://doi.org/10.3726/978-3-0351-0934-4

Dinica, M., Dinescu, L., \& Miron, C. (2012). The stimulation of students' creativity by using multimedia platforms. International Journal of Computer Science Research \& Application, 2(1), 95-100.

Doğan, A., Kaya, O., Kiliç, Z., Kiliç, E., \& Aydoğdu, M. (2004, August). Modeling the activities of scientists: Prospective science teachers ' poster presentations in an STS course. Paper presented at the 18th International Conference on Chemical Education, Chemistry Education for the Modern World, İstanbul, Turkey.

Draus, P., Curran, M., \& Trempus, M. (2014). The influence of instructor-generated video content on student satisfaction with \& engagement in asynchronous online classes. MERLOT Journal of Online Learning \& Teaching, 10(2), 240-254.

Driskill, L. (2010). Optimize your conference poster's impact. Chemical Engineering Progress, 106(8), $43-48$.

Dzekoe, R. (2013). Facilitating revision in the English as a second language (ESL) composition classroom through computer-based multimodal composing activities: A case study of composing practices of ESL students. Unpublished doctoral dissertation, Iowa State University.

El-Koumy, A., Al-Hady, T., \& Ahmed, S. (2007). The Effect of teacher-student conferences on the reading \& writing performance of ESP students. Journal of the Egyptian Association for Reading \& Knowledge, 67, 3170.

Elleman, A., \& Oslund, E. (2019). Reading comprehension research: Implications for practice \& policy. Policy Insights from the Behavioral \& Brain Sciences, 6(1), 3-11. https://doi.org/10.1177/2372732218816339

El-Sakran, T., \& Prescott, D. (2015). Schema for poster design, defense, \& assessment. Teaching English for Specific \& Academic Purposes, 3(1), 101-114.

Field, J., Schmidt-Hertha, B., \& Waxenegger, A. (Eds.). (2015). Universities \& engagement: International perspectives on higher education \& lifelong learning. London: Routledge.

Fletcher, L. (2019). How can personal development lead to increased engagement? The roles of meaningfulness \& perceived line manager relations. The International Journal of Human Resource Management, 30(7), 12031226. https://doi.org/10.1080/09585192.2016.1184177

Fraser, J., Fuller, L., \& Hutber, G. (2009). Creating effective conference abstracts \& posters in Biomedicine: 500 tips for success. New York: Radcliffe.

Fredricks, J., \& McColskey, W. (2012). The measurement of student engagement: A comparative analysis of various methods \& student self-report instruments. In S. Christenson, A. Reschly \& C. Wylie (Eds.), Handbook of research on student engagement (pp. 763-782). New York: Springer. https://doi.org/10.1007/978-1-4614-2018-7_37

Fredricks, J., Reschly, A., \& Christenson, S. (2019). Conclusion: Status of student engagement interventions. In J. Fredricks, A. Reschly \& S. Christenson (Eds.), Handbook of student engagement interventions (pp. 375-389). London: Academic Press. https://doi.org/10.1016/B978-0-12-813413-9.00025-5

Fredricks, J., Ye, F., Wang, M., \& Brauer, S. (2019). Profiles of school disengagement: Not all disengaged students are alike. In J. Fredricks, A. Reschly \& S. Christenson (Eds.), Handbook of student engagement interventions (pp. 31-43). London: Academic Press. https://doi.org/10.1016/B978-0-12-813413-9.00003-6

Gambrell, L., Hughes, E., Calvert, L., Malloy, J., \& Igo, B. (2011). Authentic reading, writing, \& discussion: An exploratory study of a pen pal project. Elementary School Journal, 112(2), 234-258. https://doi.org/10.1086/661523

Gastel, B., \& Day, R. (2016). How to write \& publish a scientific paper (8th ed.). Greenwood, Santa Barbara, CA: ABC-CLIO.

Ghaith, G. (2018). English as a second/foreign language reading comprehension: A framework for curriculum \& instruction. TESL Reporter, 50(2), 1-17.

Grabe, W., \& Stoller, F. (2011). Teaching \& researching: Reading (2nd ed.). New York, NY: Routledge. https://doi.org/10.1002/9781405198431.wbeal1174 
Guthrie, J., \& Klauda, S. (2015). Engagement \& motivational processes in reading. In P. Afflerbach (Ed.), Handbook of individual differences in reading: Reader, text \& context (pp. 41-53). New York: Routledge.

Hai-Jew, S. (2012). Adding self-discovery learning to live online conferences: Using digital poster sessions in higher education. In U. Demiary, G. Kurubacak \& T. Volkan Yuzer (Eds.), Meta-communication for reflective online conversations: Models for distance education (pp. 265-281). Hershey, PA: Information Science Reference. https://doi.org/10.4018/978-1-61350-071-2.ch016

Hasio, C. (2015). Visual inspirations: The pedagogical \& cultural significance of creative posters in the art classroom. Journal of College Teaching \& Learning, 12(1), 39-44. https://doi.org/10.19030/tlc.v12i1.9068

Hassan, E. (2015). The effectiveness of concept-oriented reading instruction approach in developing EFL reading comprehension skills \& reading motivation for experimental preparatory school pupils. Unpublished doctoral dissertation, Banha University, Egypt.

Hellekjaer, G. (2009). Academic English reading proficiency at the university level: A Norwegian case study. Reading in a Foreign Language, 21(2), 198-222. https://doi.org/10.5617/adno.1022

Hodgson, K. (2010). Digital posters: Composing with an online canvas. Retrieved January 17, 2016 from http://www.learnnc.org/lp/pages/6542

Huang, H. (2014). Online versus paper-based instruction: Comparing two strategy training modules for improving reading comprehension. RELC Journal, 45(2), 165-180. https://doi.org/10.1177/0033688214534797

Huffman, J. (2014). Reading rate gains during a one-semester extensive reading course. Reading in a Foreign Language, 26(2), 17-33.

Hunter, A. (2009). Join the literacy club. Principal Leadership, 9(9), 36-39.

Ilic, D., \& Rowe, N. (2013). What is the evidence that poster presentations are effective in promoting knowledge transfer? A state-of-the-art review. Health Information \& Libraries Journal, 30(1), 4-12. https://doi.org/10.1111/hir.12015

Izatt, S., \& Dadiz, R. (2015). Educational perspectives: Effective visual display of poster presentations. New Reviews, 16(4), e203-e210. https://doi.org/10.1542/neo.16-4-e203

Jamaludin, R., \& Osman, S. (2014). The use of a flipped classroom to enhance engagement \& promote active learning. Journal of Education \& Practice, 5(2), 124-131.

Juergensen, J., Oestreich, T., Yuhnke, B., \& Kenney, M. (2015). Active learning at Case Western University. Educause Review. Retrieved December 29, 2018 from http://er.educause.edu/articles/2015/1/active-learning-at-case-western-university

Kahu, E., \& Nelson, K. (2018). Student engagement in the educational interface: Understanding the mechanisms of student success, Higher Education Research \& Development, 37(1), 58-71. https://doi.org/10.1080/07294360.2017.1344197

Kazamel, S. (2018). Using concept maps strategy for developing the English reading comprehension skills \& attitudes of preparatory students. Unpublished master's thesis, Ain Shams University, Egypt.

Khori, M., \& Ahmad, A. (2019, January). Enhancing students' reading comprehension through the collaboration between reciprocal teaching \& cooperative learning. Proceedings of the International Conference on Innovation in Education (ICoIE 2018). Amsterdam, the Netherlands: Atlantis Press. https://doi.org/10.2991/icoie-18.2019.122

Kinikin, J., \& Hench, K. (2012). Poster presentations as an assessment tool in a third/college level information literacy course: An effective method of measuring student understanding of library research skills. Journal of Information Literacy, 6(2), 86-96. https://doi.org/10.11645/6.2.1698

Kong, J. (2019). Theories of reading comprehension. In J. Kong (Ed.), Investigating the role of test methods in testing reading comprehension: A process-focused perspective (pp. 9-29). Springer, Singapore. https://doi.org/10.1007/978-981-13-7021-2_2

Kuh, G. (2009). What student affairs professionals need to know about student engagement. Journal of College Student Development, 50(6), 683-706. https://doi.org/10.1353/csd.0.0099

Lagares, M., \& Reisenleutner, S. (2017). Rotating poster presentations. In C. Álvarez-Mayo, A. Gallagher-Brett \& F. Michel (Eds.), Innovative language teaching \& learning at university: Enhancing employability (pp. 7987). Dublin, Ireland: Research-publishing.net. https://doi.org/10.14705/rpnet.2017.innoconf2016.657 
Leece, R., \& Campbell, E. (2011). Engaging students through social media. Journal of the Australian \& New Zealand Student Services Association, 38, 10-15.

Liao, H., \& Oescher, J. (2009). Does cooperative learning really enhance self-efficacy \& task value of English grammar learners? Journal of Education \& Psychology, 32(3), 24-54.

Liu, P., Chen, C., \& Chang, Y. (2010). Effects of a computer-assisted concept mapping learning strategy on EFL college students' in English reading comprehension. Computers \& Education, 54(2), 436-445. https://doi.org/10.1016/j.compedu.2009.08.027

Lyddon, P., \& Selwood, J. (2017). Re-mediating postmillennial posters. In K. Borthwick, L. Bradley \& S. Thouësny (Eds.), CALL in a climate of change: Adapting to turbulent global conditions-short papers from EUROCALL 2017 (pp. 200-204). Dublin, Ireland: Research-publishing.net. https://doi.org/10.14705/rpnet.2017.eurocall2017.713

Malin, G. (2010). Is it still considered reading? Using digital video storytelling to engage adolescent readers. Clearing House, 83(4), 121-125. https://doi.org/10.1080/00098651003774802

Mareye, M. (2019). The effect of a suggested program based on self-regulated learning strategies on mastering some reading comprehension skills for EFL students. Unpublished master's thesis, Assiut University, Egypt.

Martin, F., \& Bolliger, D. (2018). Engagement matters: Student perceptions on the importance of engagement strategies in the online learning environment. Online Learning, 22(1), 205-222. https://doi.org/10.24059/olj.v22i1.1092

Martinez-Alba, G., Cruzado-Guerrero, J., \& Pitcher, S. (2014). Glogsters \& other motivating technology: A multiple case study of English learners. The Reading Matrix, 14(2), 253-262.

Masters, K., Gibbs, T., \& Sandars, J. (2015). How to make an effective e-poster. MedEdPublish, 1, 1-9. https://doi.org/10.15694/mep.2015.004.0001

McGeown, S. (2013). Reading motivation \& engagement in the primary school classroom: Theory, research, \& practice. Leicester, UK: United Kingdom Literacy Association.

McNamara, J., Larkin, I., \& Beatson, A. (2010) Using poster presentations as assessment of work integrated learning. Proceedings of the Australian Collaborative Education Network National Conference. Curtin University of Technology, Perth: Australian Collaborative Education Network.

Mohamed, M. (2013). The effectiveness of the language experience approach in developing some EFL reading \& writing skills among primary school pupils. Unpublished master's thesis, Banha University, Egypt.

Molloy, J., \& Boyle, S. (2014). Eposter design: A leap into the unknown. SCONUL Focus, 62, 24-27.

Moore, M., \& Hall, S. (2012). Listening \& reading comprehension at story time: How to build habits of the mind. Dimensions of Early Childhood, 40(2), 24-31.

Morales, M., \& Morales, M. (2017). The use of poster sessions to develop professionalism, domain five of the Ecuadorian national English teachers' standards. English Language Teaching, 10(7), 21-42. https://doi.org/10.5539/elt.v10n7p21

Murdiani, A. (2013). The reading comprehension of recount text of the eighth-grade students of Smp Nu Al Ma'ruf Kudus in academic year 2012/2013 taught by using poster. Unpublished master's thesis, University of Muria Kudus, Malaysia.

Mustafa, M., Naidu, V., Mohammed, Q., Jesrani, K., Hasan, R., \& Al Hadrami, G. (2019). A framework for collaborative \& active learning for enhancing student engagement. International E-Journal of Advances in Education, 5(13), 83-93. https://doi.org/10.18768/ijaedu.531644

Nation, I. (2009). Teaching ESL/EFL reading \& writing. New York, NY: Routledge. https://doi.org/10.4324/9780203891643

National Survey of Student Engagement. (2014). Retrieved March 12, 2016 from http://nsse.indiana.edu

Nora, A., Crisp, G., \& Matthews, C. (2011). A reconceptualization of CCSSE's benchmarks of student engagement. Review of Higher Education, 35(1), 105-130. https://doi.org/10.1353/rhe.2011.0036

Pan, C., \& Wu, H. (2013). The cooperative learning effects on English reading comprehension \& learning motivation of EFL freshmen. English Language Teaching, 6(5), 13-27. https://doi.org/10.5539/elt.v6n5p13

Pedwell, R., Hardy, J., \& Rowland, S. (2017). Effective visual design \& communication practices for research 
posters: Exemplars based on the theory \& practice of multimedia learning \& rhetoric. Biochemistry \& Molecular Biology Education, 45(3), 249-261. https://doi.org/10.1002/bmb.21034

Peregoy, S., \& Boyle, O. (2016). Reading, writing, \& learning in ESL: A resource book for teaching K-12 English learners (7th ed.). Boston, MA: Pearson.

Pernjek, J., \& Habjanec, M. (2015). Developing reading skills \& motivation through mobile phones (pp. 397-407). Proceedings of the INFuture2015 Conference, e-Institutions: Openness, Accessibility, \& Preservation. Zagreb, Croatia. https://doi.org/10.17234/INFUTURE.2015.41

Pitcher, S., Martinez-Alba, G., Dicembre, E., Fewster, D., \& McCormick, M. (2010). The literacy needs of adolescents in their own words. Journal of Adolescent \& Adult Literacy, 53(8), 636-645. https://doi.org/10.1598/JAAL.53.8.2

Pond, K. (2016). Student engagement in video case based undergraduate business teaching. International Journal of Higher Education, 5(1), 119-127. https://doi.org/10.5430/ijhe.v5n1p119

Popkess, A. (2010). The relationship between undergraduate, baccalaureate nursing student engagement \& use of active learning strategies in the classroom. Unpublished Doctoral Dissertation, Indiana University.

Pratama, E. (2015, October). The implementation of blended learning method using Edmodo (a social networking site) in teaching reading comprehension. Paper presented at the International Conference on Language, Literature, Culture, \& Education. Kuala Lumpur, Malaysia.

Prichard, C., \& Ferreira, D. (2014). The effects of poster presentations \& class presentations on low-proficiency learners. TESOL Journal, 5(1), 172-185. https://doi.org/10.1002/tesj.131

Pugalee, D. (2015). Effective content reading strategies to develop mathematical \& scientific literacy: Supporting the common core state standards \& the next generation science standards. Rowman \& Littlefield.

Reeve, J. (2013). How students create motivationally supportive learning environments for themselves: The concept of agentic engagement. Journal of Educational Psychology, 105(3), 579-595. https://doi.org/10.1037/a0032690

Reeve, J., \& Tseng, C. (2011). Agency as a fourth aspect of student engagement during learning activities. Contemporary Educational Psychology, 36(4), 257-267. https://doi.org/10.1016/j.cedpsych.2011.05.002

Richardson, W. (2010). Blogs, wikis, podcasts \& other powerful web tools for classrooms (3rd ed.). California: Corwin Press.

Roessing, L. (2014). Bridging the gap: Reading critically \& writing meaningfully to get to the core. New York: Rowman \& Littlefield.

Rowe, N., \& Ilic, D. (2009). What impact do posters have on academic knowledge transfer? A pilot survey on author attitudes \& experiences. BMC Medical Education, 9(71), 1-7. https://doi.org/10.1186/1472-6920-9-71

Rushton, D., Middleton, A., \& Malone, C. (2014). Digital posters: Talking cycles for academic literacy. In T. Lillis, K. Harrington, M. Lea \& S. Mitchell (Eds.), Working with academic literacies: Case studies towards transformative practice (pp. 299-306). Fort Collins, Colorado: The WAC Clearinghouse \& Parlor Press.

Sabo, L. (2013). Social awareness posters: Inspiring creativity in boys. International Boys' Schools Coalition action research program. Retrieved December 27, 2017 from https://www.theibsc.org/uploaded/IBSC/Action_Reseach/AR_2012-13/Sabo_Poster.pdf

Sadik, A. (2008). Digital storytelling: A meaningful technology-integrated approach for engaged student learning. Educational Technology Research \& Development, 56(4), 487-506. https://doi.org/10.1007/s11423-008-9091-8

Salemi, M. (2009). Clickenomics: Using a classroom response system to increase student engagement in the principles of economics course. Journal of Economic Education, 40(4), 385-404. https://doi.org/10.1080/00220480903237950

Saver, C. (2014). Anatomy of writing for publication for nurses (2nd ed.). Indianapolis, IN: Sigma Theta Tau.

Shin, J., Dronjic, V., \& Park, B. (2019). The interplay between working memory \& background knowledge in L2 reading comprehension. TESOL Quarterly, 53(2), 320-347. https://doi.org/10.1002/tesq.482

Shin, S. (2012). Evaluation of electronic versus traditional format poster presentations. Medical Education, 46(5), 519-520. https://doi.org/10.1111/j.1365-2923.2012.04253.x 
Soliman, Y. (2014). The effectiveness of using a program based on using mini-drama upon developing faculty of education third year English majors' target culture knowledge \& reading comprehension. Unpublished master's thesis, Minia University, Egypt.

Stegemann, N., \& Sutton-Brady, C. (2009). Poster sessions in marketing education: An empirical examination. Journal of Marketing Education, 31, 219-229. https://doi.org/10.1177/0273475309344998

Suh, J. (2009). Reading concepts in cooperative work by EFL college students. English Teaching, 64(2), 151-171. https://doi.org/10.15858/engtea.64.2.200906.151

Suk, N. (2017). The effects of extensive reading on reading comprehension, reading rate, \& vocabulary acquisition. Reading Research Quarterly, 52(1), 73-89. https://doi.org/10.1002/rrq.152

Sun, J., \& Rueda, R. (2012). Situational interest, computer self-efficacy, \& self-regulation: Their impact on student engagement in distance education. British Journal of Educational Technology, 43(2), 191-204. https://doi.org/10.1111/j.1467-8535.2010.01157.x

Tanner, P., \& Chapman, J. (2012). Poster presentations speak for themselves. The Language Teacher, 36(3), 1520.

Wolf-Wendel, L., Ward, K., \& Kinzie, J. (2009). A tangled web of terms: The overlap \& unique contribution of involvement, engagement, \& integration to understanding college student success. Journal of College Student Development, 50(4), 407-428. https://doi.org/10.1353/csd.0.0077

Yang, C., \& Hsu, T. (2015). Applying semiotic theories to graphic design education: An empirical study on poster design teaching. International Education Studies, 8(12), 117-129. https://doi.org/10.5539/ies.v8n12p117

You, S., \& Sharkey, J. (2009). Testing a developmental-ecological model of student engagement: A multilevel latent growth curve analysis. Educational Psychology, 29(6), 659-684. https://doi.org/10.1080/01443410903206815

\section{Copyrights}

Copyright for this article is retained by the author, with first publication rights granted to the journal.

This is an open-access article distributed under the terms and conditions of the Creative Commons Attribution license (http://creativecommons.org/licenses/by/4.0/). 